\title{
Inhibitory Effects of ATP and Adenosine on Cholangiocarcinoma Cell Proliferation and Motility
}

\author{
JOMNARONG LERTSUWAN ${ }^{1}$ and MATHUROS RUCHIRAWAT ${ }^{2}$ \\ ${ }^{1}$ Laboratory of Chemical Carcinogenesis, Chulabhorn Research Institute, Bangkok, Thailand; \\ ${ }^{2}$ Laboratory of Environmental Toxicology, Chulabhorn Research Institute, Bangkok, Thailand
}

\begin{abstract}
Background/Aim: Inhibitory effects of extracellular nucleotides have been investigated in many types of cancers. Herein, we aimed to determine the effects of ATP and adenosine and their receptor profile on cholangiocarcinoma (CCA) cells. Materials and Methods: Two CCA and one immortalized cholangiocyte cell line were used. The effects of ATP and adenosine on cell proliferation and motility were examined by MTT and woundhealing/trans-well invasion assays, respectively. Purinergic receptor profiling was carried out by reverse transcriptionpolymerase chain reaction (RT-PCR). Results: ATP and adenosine induced proliferation-inhibitory and motilityinhibitory effects in all cell lines tested. However, immortalized cholangiocytes showed resistance in proliferation inhibition. Several $P 2$ receptors were commonly expressed in all cells, whereas no adenosine receptor was expressed. Furthermore, no synergistic effects of ATP and adenosine were observed in CCA cells. Conclusion: ATP and adenosine had anti-proliferative and anti-motility effects in CCA cells, while there was a smaller effect on normal cholangiocytes. These data indicate the potential use of ATP and odenosine as a novel therapy for CCA.
\end{abstract}

Cholangiocarcinoma (CCA) is a silent and lethal disease. The incidence of CCA is increasing worldwide (1-3). The highest incidence rate is in Southeast Asia (4), particularly in the northeastern provinces of Thailand, where the incidence has been reported to be as high as 115 per 100,000 males (5). Patients are usually diagnosed with locally

Correspondence to: Dr. Jomnarong Lertsuwan, Laboratory of Chemical Carcinogenesis, Chulabhorn Research Institute, 54 Kamphaeng Phet 6, Talat Bang Khen, Lak Si, Bangkok 10210, Thailand. Tel: +66 25538555 ext 8272, Fax: +66 25538572, e-mail: jomnarong@cri.or.th

Key Words: ATP, adenosine, purinergic receptor, cholangiocarcinoma, growth inhibition, motility inhibition. advanced or metastatic disease. Unfortunately, current chemotherapies are not effective against CCA and no randomized trial has demonstrated a curative benefit of a systemic therapy yet (6). Surgery is still the only curable treatment option (7).

New therapeutic strategies and novel compounds for CCA treatment are being sought. One of the emerging therapeutic agents for cancer is ATP. ATP signals through a subfamily of purinergic receptors known as $\mathrm{P} 2 \mathrm{Y}$ and $\mathrm{P} 2 \mathrm{X}$ receptors. Also, ATP could be hydrolyzed into adenosine and signal through adenosine receptors. Effects of ATP and adenosine on cancers vary depending on the cancer type, potentially due to the differential expression of purinergic receptors on each cancer type, and the dosage of extracellular ATP or adenosine used (8-10). Short- and long-term (trophic) purinergic signaling in humans has been studied in both normal and pathogenic conditions, including cancer (11-15). Some researchers have suggested the variable responses of cancer cells to extracellular nucleotides. Extracellular ATP inhibited growth and motility of nasopharyngeal carcinoma cells by inducing apoptosis through P2Y2 receptor (16). $\mathrm{P} 2 \mathrm{X} 7$, as one of the ATP receptors, was shown to mediate pyroptosis from cytosolic LPS and a catalytic activity of caspase-11 (17). In addition, $\mathrm{P} 2 \mathrm{X} 7$ receptor was shown to be a critical player in antitumor immune responses in mice. Tumor growth and metastatic spread were accelerated strongly in mice lacking the $\mathrm{P} 2 \mathrm{X} 7$ receptor (18). On the other hand, some studies have shown an induction in the proliferation of human hepatocellular carcinoma cells in vitro and in vivo (19) and an increase of cell invasion in prostate cancer cells $(20,21)$ via an activation of the P2Y2 receptor. ATP at a low dose $(1 \mu \mathrm{M})$ also induced cell-cycle progression in MCF-7 cells (22), and increased breast cancer MDA-MB-231 cell proliferation via the P2Y2 receptor (23). Nevertheless, high dose of ATP induced cell death through P2X7 and AMPK/mTOR signaling in colon cancer cells (24). In addition, $\mathrm{P} 2 \mathrm{X} 7$ receptor is required to mediate cell death in lung cancer cells (25). Herein, the inhibitory effects of ATP and adenosine on CCA cell lines were revealed. 


\section{Materials and Methods}

Cell culture. All cell lines were maintained as described previously (26-28). HuCCA-1 and RMCCA-1 were maintained in HAM's F-12 medium (Hyclone, Pittsburgh, PA. USA) supplemented with $10 \%$ fetal bovine serum (FBS) (Gibco, Grand Island, NY, USA), while MMNK1 were maintained in Dulbecco's modified Eagle's medium (DMEM) (Hyclone, Pittsburgh, PA. USA) supplemented with 10\% FBS. 1\% Penicillin/Streptomycin (Gibco, Grand Island, NY, USA) was added in all media. All cell lines were maintained at $37^{\circ} \mathrm{C}$ with $5 \% \mathrm{CO}_{2}$.

Cell proliferation assay. Cells were plated with suitable medium in tissue culture treated 48-well plates. After overnight adhesion to the plate, the treatment group was incubated with the indicated concentrations of agonists ranging from $\log$ [agonist] $=-5.5(3.16 \mu \mathrm{M})$ to $\log$ [agonist] $=-2.5(1000 \mu \mathrm{M})$ in a half $\log$ increment. Ten and $100 \mu \mathrm{M}$ of ATP $\gamma \mathrm{S}$ (Abcam, Cambridge, MA, USA) and 2 units of apyrase (Sigma-Aldrich, St. Louis, MO, USA) was added to assess the effects of non-hydrolysable ATP analog and degradation products. Media were changed and new treatments were added every other day for 4 days. MTT reagent (Life Technologies, Grand Island, NY, USA) was added to the final concentration of $0.5 \mathrm{mg} / \mathrm{mL}$ and incubated for $2.5 \mathrm{~h}$ at $37^{\circ} \mathrm{C}$, and then a half volume of stop solution ( $10 \%$ SDS in $50 \%$ dimethylformamide in $\mathrm{dH}_{2} \mathrm{O}$ ) was added and mixed thoroughly before reading the absorbance at $560 \mathrm{~nm}$ and $650 \mathrm{~nm}$ on a plate reader.

Cell migration assay. Cells were plated in $60 \mathrm{~mm}$ tissue culture discs with suitable medium to achieve $100 \%$ confluence after overnight incubation. A single scratch was made at the middle of the dish by using $100 \mu \mathrm{L}$ siliconized pipette tip. The cells were incubated with ATP or adenosine at their $\mathrm{IC}_{50}$ values in new media. Pictures were taken every $6 \mathrm{~h}$ at the same locations along the gap to observe a progression of cell migration by using Nikon TMS inverted microscope mounted with Nikon D3000 digital SLR camera under $4 \times$ objective lens. Distance of migration was analyzed using Adobe Photoshop software.

Cell invasion assay. The insert transwells with $8.0 \mu \mathrm{m}$ polycarbonate membrane (Corning costar, New York, NY, USA) was coated with $50 \mu \mathrm{l}$ of a 1:10 mixture of Matrigel ${ }^{\mathrm{TM}}$ (BD Biosciences, San Jose, CA, USA) in serum free medium, and then allowed to congeal at $37^{\circ} \mathrm{C}$ for $30 \mathrm{~min}$. A total of $5 \times 10^{4}$ cells were added to the top chamber of each well in $200 \mu$ l serum free medium. Then, $500 \mu \mathrm{L}$ of complete medium was added to each bottom well. Treatment was added in both transwell and bottom well. Cells were incubated for $24 \mathrm{~h}$ in a $37^{\circ} \mathrm{C}$, humidified incubator with $5 \% \mathrm{CO}_{2}$. After this, the chambers were swabbed with cotton swab to remove cells and Matrige ${ }^{\mathrm{TM}}$ remaining on the top of the membrane. Cells remaining on the underside of the membrane were fixed in methanol for $5 \mathrm{~min}$ and stained with $0.5 \%(\mathrm{w} / \mathrm{v})$ crystal violet in $12 \%$ glutaraldehyde in water for $5 \mathrm{~min}$. Following a brief $\mathrm{dH}_{2} \mathrm{O}$ wash, cells were counted using phase contrast microscopy.

Reverse transcriptase polymerase chain reaction. Total RNA was extracted using TRIzol reagent (Life Technologies, Grand Island, NY, USA). Following extraction, RNA was treated with RNAse-free DNase I (Roche, Indianapolis, IN, USA). Total RNA was reverse transcribed using Maloney murine leukemia virus (M-MLV) reverse transcriptase (Life Technologies, Grand Island, NY, USA).
Table I. Primer sequences for purinergic receptors. Rev: Reverse, For: Forward. Splice variations ( $v$ ) of each gene, if presence, are shown in "expected product size" column.

\begin{tabular}{|c|c|c|}
\hline Gene & Forward primer & $\begin{array}{l}\text { Expected } \\
\text { product size } \\
\text { (base pair) }\end{array}$ \\
\hline P2Y1 For & GTTAGACGCCCCGAAACTGA & 254 \\
\hline P2Y1 Rev & CAACGCCGAGCTTACACAAC & \\
\hline P2Y2 For & TTCCTGTTTCCCGCAGAGTT & $\begin{array}{c}328(\mathrm{v} 1) \\
194(\mathrm{v} 2,3)\end{array}$ \\
\hline P2Y2 Rev & CACCTGTAGCCCAGCTCATC & \\
\hline P2Y4 For & CTGCCTGTGAGCTATGCAGT & 154 \\
\hline $\mathrm{P} 2 \mathrm{Y} 4 \mathrm{Re}$ & GCAGCGACAGCACATACAAG & \\
\hline P2Y6 For & ACCCTAAACCTTGCTCTGGC & 177 (all) \\
\hline P2Y6 Rev & CTGGAAGCTGATGCAGGTGA & \\
\hline P2Y11 For & CTTGAACCTCAGGAGGGTTGTG & 282 \\
\hline P2Y11 Rev & CACAGGAAGTCCCCCTGGAA & \\
\hline P2Y12 For & GCCACTCTGCAGGTTGCAATA & 224 (all) \\
\hline P2Y12 Rev & TCGCCAGGCCATTTGTGAT & \\
\hline P2Y13 For & TGCCGCCATAAGAAGACAGAG & 173 \\
\hline P2Y13 Rev & GGATGCCGGTCAAGAAAACC & \\
\hline P2Y14 For & CAAACGCTCACTGGGCAAAA & 376 \\
\hline P2Y14 Rev & TGCACACAAACACGTTCAGC & \\
\hline P2X1 For & TCTACGTCATCGGGTGGGT & 276 \\
\hline P2X1 Rev & GGGTACAGCCACTGTCTTCC & \\
\hline P2X2 For & CСАСТTCTCCAAGGGCAACA & 374 \\
\hline P2X2 Rev & CCTGTCCATGCACAATGACG & \\
\hline P2X3 For & CTGAGAAAAGCAGCGTGTCC & 210 \\
\hline P2X3 Rev & AGAGAACAGTTCCCACTCCCA & \\
\hline P2X4 For & GGTCAGCTCCGTTACGACC & 187 \\
\hline P2X4 Rev & CGCATCTGGAATCTCGGGG & \\
\hline P2X5 For & TGGAAACGGAGTGAAGACCG & $169(445$ \\
\hline P2X5 Rev & GGGGAAACGGATGTGGTTCT & $\begin{array}{c}\text { in positive } \\
\text { control due to } \\
\text { an intron span } \\
\text { between primers) }\end{array}$ \\
\hline P2X6 For & AGGGGTTTCCGTCACTCAGA & 238 \\
\hline P2X6 Rev & GCCTGTTTTTACACCGTGGC & \\
\hline P2X7 For & AGCGGAAAGAGCCTGTCATC & 242 \\
\hline P2X7 Rev & GTCAGAGGAACAGAGCGTCC & \\
\hline A1 For & CAACATTGGGCCACAGACCT & 222 \\
\hline A1 Rev & ATAGGGGTCAGTCCCACCAC & \\
\hline A2A For & ATCGCCATTGACCGCTACAT & 493 \\
\hline A2A Rev & AGTCGGGGCAGAAGAAAGTG & \\
\hline A2b For & GGGCTTCTGCACTGACTTCT & 175 \\
\hline A2b Rev & AGCAATGACCCCTCTTGCTC & \\
\hline A3 For & CACCTGTGATGAGCCCTTTCT & 577 \\
\hline A3 Rev & GTGAGTGGTGACCCTCTTGT & \\
\hline GAPDH For & CACCGTCAAGGCTGAGAACG & 223 \\
\hline GAPDH Rev & GACGAACATGGGGGCATCAG & \\
\hline
\end{tabular}

Polymerase chain reaction (PCR) was carried-out using helixamp Taq (Nanohelix, Yuseong-Gu, Daejeon, Korea) for 32 cycles. PCR reaction was carried out with $2 \mathrm{mM} \mathrm{MgCl} 2,0.2 \mathrm{mM}$ dNTP, $1 \mu \mathrm{M}$ of forward and reverse primers (Integrated DNA technology, Coralville, Iowa, USA), $0.025 \mathrm{U} / \mu \mathrm{l}$ of Taq polymerase in $10 \mu \mathrm{l}$ total volume. Primer sequences are shown in Table I. Five microliters of each reaction mixture was mixed with NovelJuice (Gendirex) and 

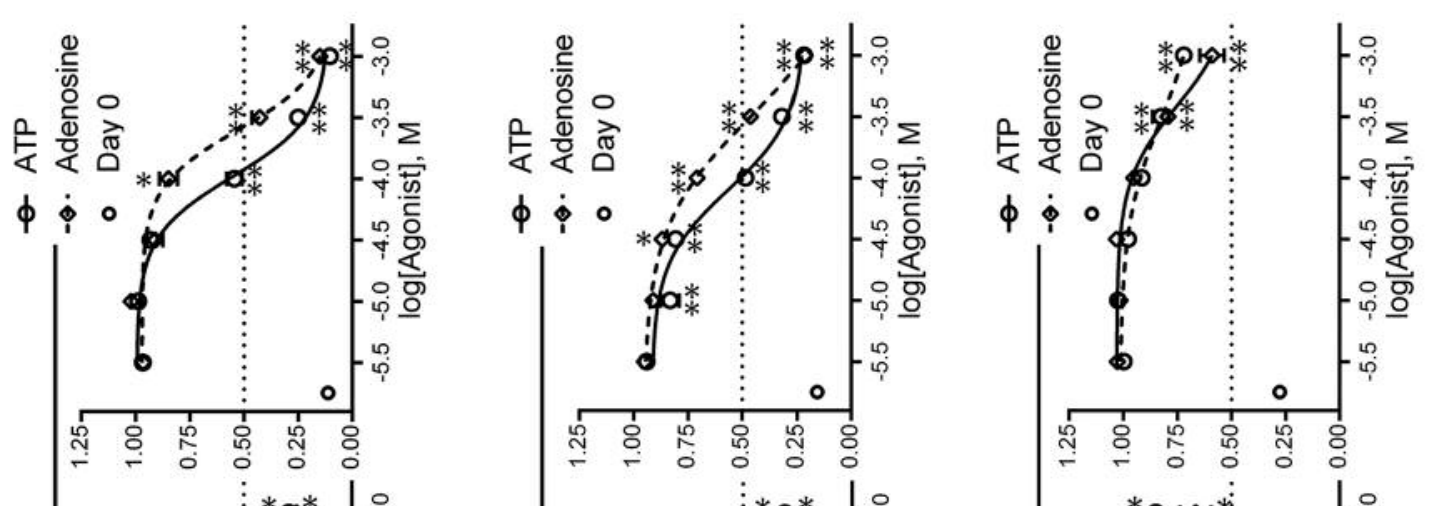

ํ. 0.5

11.

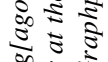
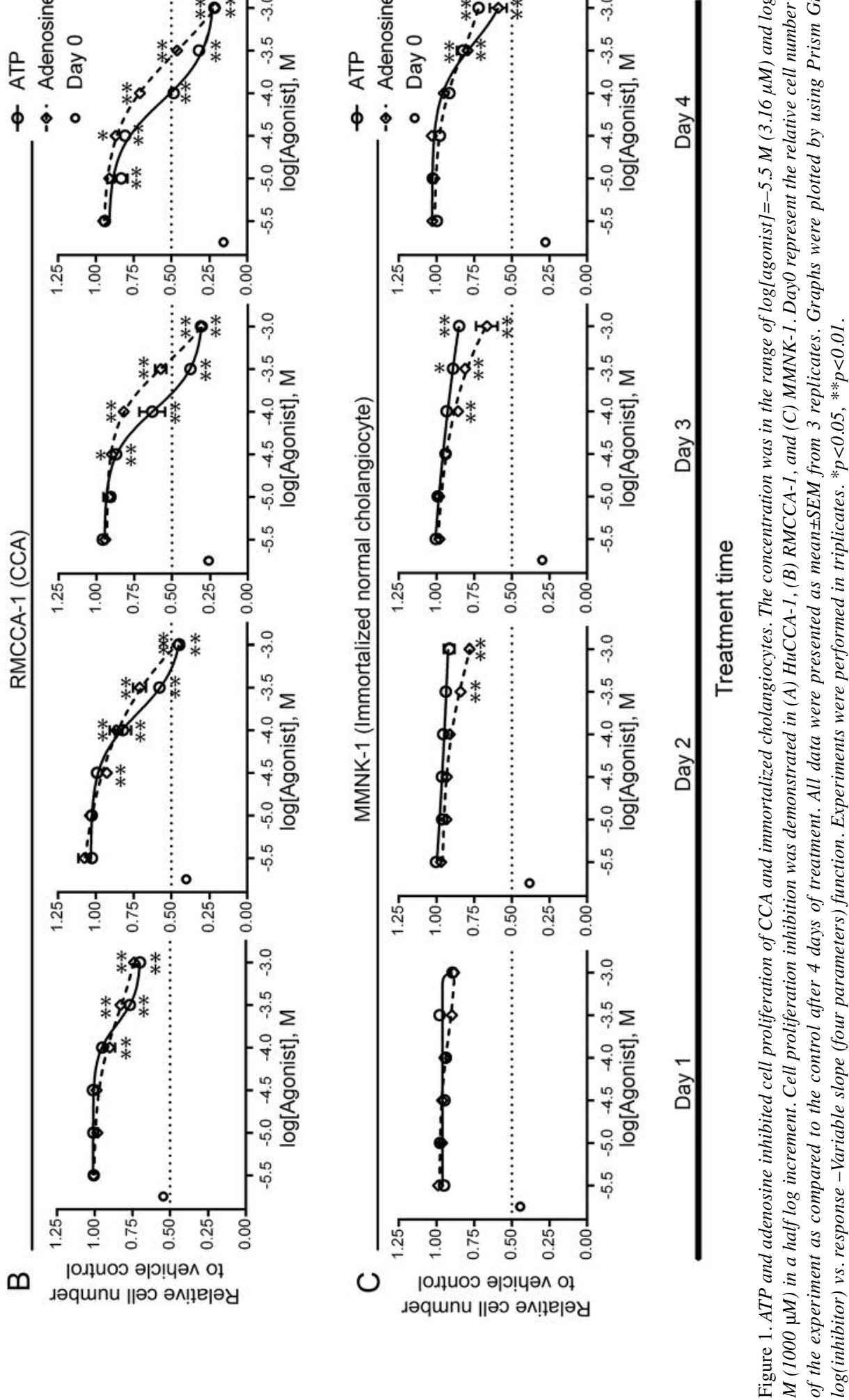
electrophoresed in $1.5 \%$ agarose gel at $100 \mathrm{~V}$ for $45 \mathrm{~min}$ at room temperature. 100bp DNA ladder (Bio-Helix, Beverly, MA, USA) was used to compare product size. Positive controls were performed by using HuCCA-1 genomic DNA.

Statistical analysis. Data were graphed as mean \pm SEM by using Prism Graphpad software. Statistical analysis was performed using ANOVA with Dunnett's test by using JMP software. All experiments were performed in triplicates.

\section{Results}

ATP and adenosine inhibited CCA cell proliferation. ATP and adenosine inhibited CCA cell proliferation in a dose- and timedependent manner. Time dependent response of ATP could be seen in all dosages for HuCCA1 and RMCCA-1. One hundred micromolar ATP $(\log [\mathrm{ATP}]=-4.0)$ was able to inhibit HuCCA1 approximately $20 \%$ at 1 day after treatment. The inhibitory effect increased to $25 \%, 35 \%$, and $50 \%$ at days 2, 3, and 4 respectively (Figure 1A). A similar trend was observed in RMCCA-1 with asmaller degree of inhibition (Figure 1B). However, $\mathrm{IC}_{50}$ of ATP on HuCCA-1 and RMCCA-1 at 4 days was equal at $120 \mu \mathrm{M}$. On the other hand, adenosine showed less cell proliferation inhibition on HuCCA-1 (Figure 1A) and RMCCA-1 (Figure 1B), compared to ATP. Adenosine had $\mathrm{IC}_{50}$ at $260 \mu \mathrm{M}$ on both HuCCA-1 and RMCCA-1. Interestingly, ATP had no inhibitory effect on MMNK-1 cells until 3 days after treatment (Figure 1C) and reached only 25\% inhibition after 4 days with the highest dose tested. Similarly, adenosine was unable to inhibit MMNK-1 cell proliferation below 50\% (Figure 1C). Therefore, the $\mathrm{IC}_{50}$ of both ATP and adenosine for MMNK-1 was not obtained in this study.

ATP and adenosine did not synergize on CCA. A combination of ATP and adenosine at low doses $(10 \mu \mathrm{M}$ and lower) did not show any synergistic inhibitory effect on RMCCA-1 and HuCCA-1 cells (Figure 2A and 2B), while it stimulated RMCCA-1 cell proliferation (Figure 2B). On the other hand, their combination showed a synergistic inhibitory effect on MMNK-1 (Figure 2C). The combination inhibited MMNK-1 cell proliferation to lower than $50 \%$ at $1000 \mu \mathrm{M}$ while either ATP or adenosine alone had no effect.

ATP and adenosine inhibited CCA cell motility. ATP and adenosine inhibited both cell migration on cell culture disc and cell invasion through Matrigel. ATP at $\mathrm{IC}_{50}(120 \mu \mathrm{M})$, obtained from Figure 1, slowed-down HuCCA-1, RMCCA-1, and MMNK-1 cell migration to $86 \%, 83 \%$, and $82 \%$ respectively as compared to the vehicle control group at $18 \mathrm{~h}$ after treatment (Figure 3A). A stronger inhibitory effect was observed in adenosine treatment at the $\mathrm{IC}_{50}$ concetration $(260 \mu \mathrm{M})$. Cell migration of HuCCA-1, RMCCA-1, and MMNK-1 at $18 \mathrm{~h}$ of adenosine treatment was inhibited to $82 \%, 64 \%$, and $75 \%$ respectively compared to the vehicle control group (Figure

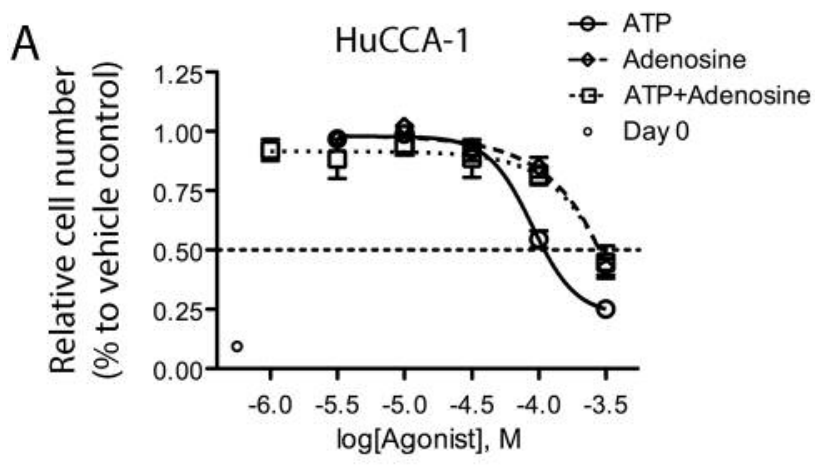

B
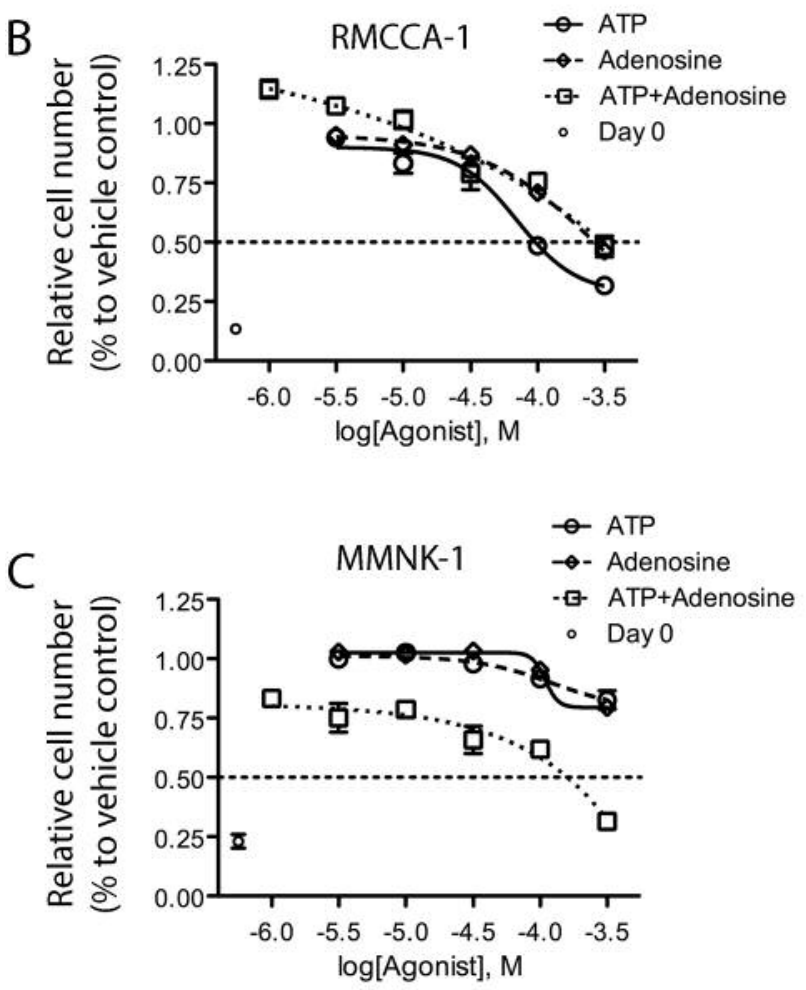

Figure 2. ATP and adenosine inhibitory effect did not synergize. The inhibitory effect on cell proliferation did not synergize on CCA cells, (A) HuCCA-1 and (B) RMCCA-1, but (C) the synergistic effect was observed on immortalized cholangiocytes (MMNK-1). Graphs were plotted by using Prism Graphad 6 with one-phase decay function. Experiments were performed in triplicates.

3A). Furthermore, ATP inhibited HuCCA-1 and RMCCA-1 cell invasion through Matrigel to approximately $66 \%$ compared to the vehicle control group. ATP had a greater inhibitory effect on MMNK-1 cell invasion (Figure 3B). Notably, adenosine had a greater effect on cell invasion as compared to ATP in all 3 cell lines. HuCCA-1 cell invasion was decreased to approximately $11 \%$ in HuCCA-1, 26\% in RMCCA-1, and $16 \%$ in MMNK-1 cells (Figure 3B). 

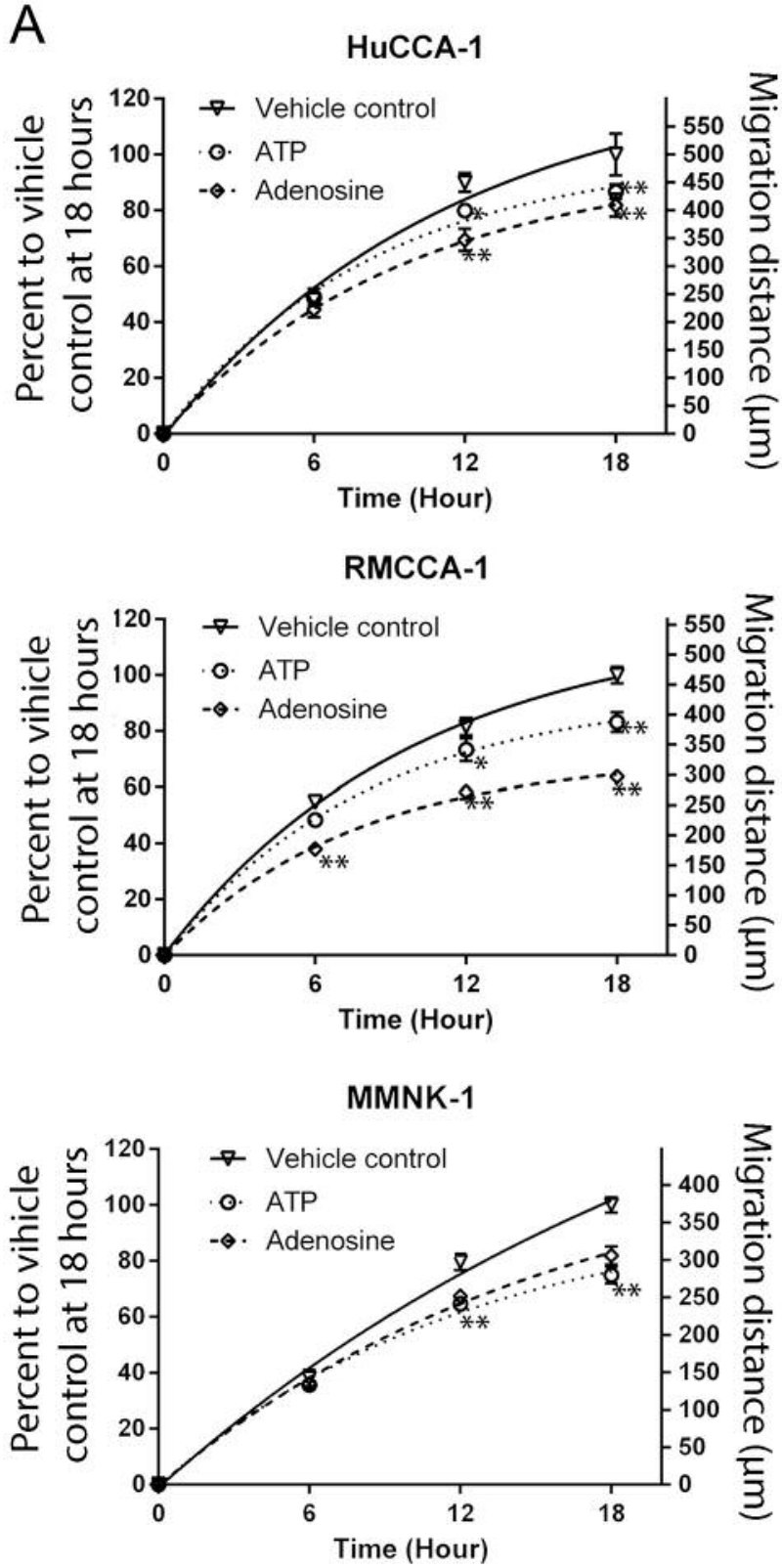

Non-hydrolysable form of ATP had a greater effect than ATP. ATP $\gamma$ S, a non-hydrolysable ATP analog, was used to verify that ATP, not its degraded byproducts ADP or AMP, inhibited CCA cell proliferation. ATP $\gamma \mathrm{S}$ showed greater inhibition on cell proliferation at both $10 \mu \mathrm{M}$ and $100 \mu \mathrm{M}$ compared to ATP on HuCCA-1 and RMCCA-1 cells. MMNK-1 cells did not respond to $10 \mu \mathrm{M}$ of both ATP and ATP $\gamma \mathrm{S}$ as expected. One hundred micromolar of ATP $\gamma \mathrm{S}$, however, showed a significantly greater inhibition as compared to ATP on MMNK-1 (Figure 4A). Furthermore, apyrase was used to degrade ATP to ADP and AMP in order to examine the

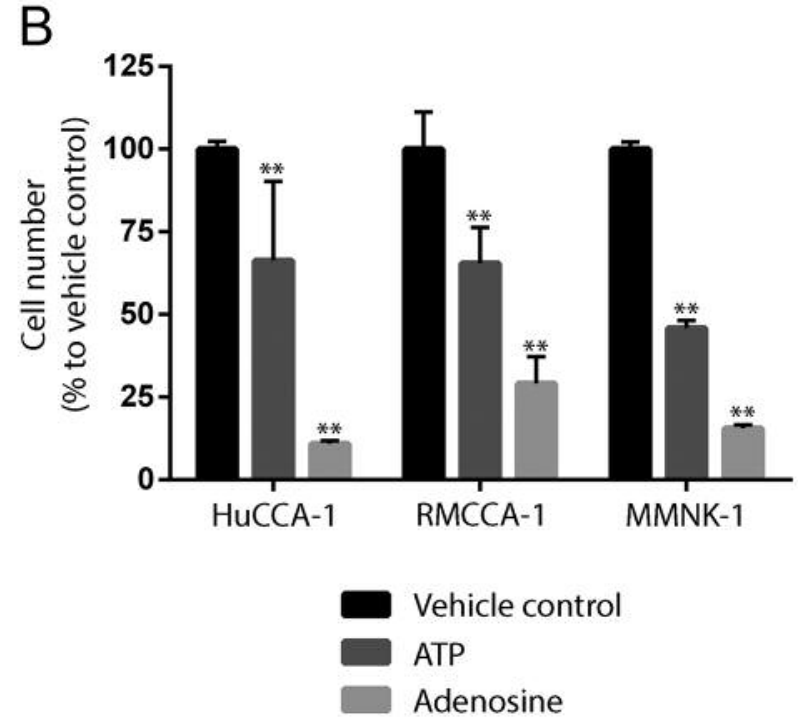

Figure 3. ATP and adenosine inhibited CCA and immortalized cholangiocytes cell motility. (A) ATP and adenosine inhibited cell migration on tissue culture disc by using the scratch assay. (B) ATP and adenosine inhibited cell invasion through Matrigel at $24 \mathrm{~h}$ after treatment. All data were presented as mean \pm SEM from 3 replicates. Graphs were plotted by using the Prism Graphpad 6 with one phase decay function. Experiments were performed in triplicates. ${ }^{*} p<0.05,{ }^{*} p<0.01$.

inhibitory effects of these degraded byproducts. Apyrase reduced the inhibitory effect of ATP $(120 \mu \mathrm{M})$ significantly in all cell lines tested (Figure 4B).

Transcriptional profile of purinergic receptors on CCA cell lines and MMNK-1. Two CCA cell lines (HuCCA-1 and RMCCA1) and one immortalized cell line (MMNK-1) expressed several purinergic receptors (Figure 5). P2Y2 and $\mathrm{P} 2 \mathrm{X} 3$ receptors were expressed in all cell lines while P2Y6, $\mathrm{P} 2 \mathrm{Y} 13$, and $\mathrm{P} 2 \mathrm{X} 7$ receptors were expressed only in CCA cell lines but not in MMNK-1 cells. P2X4 was expressed on 

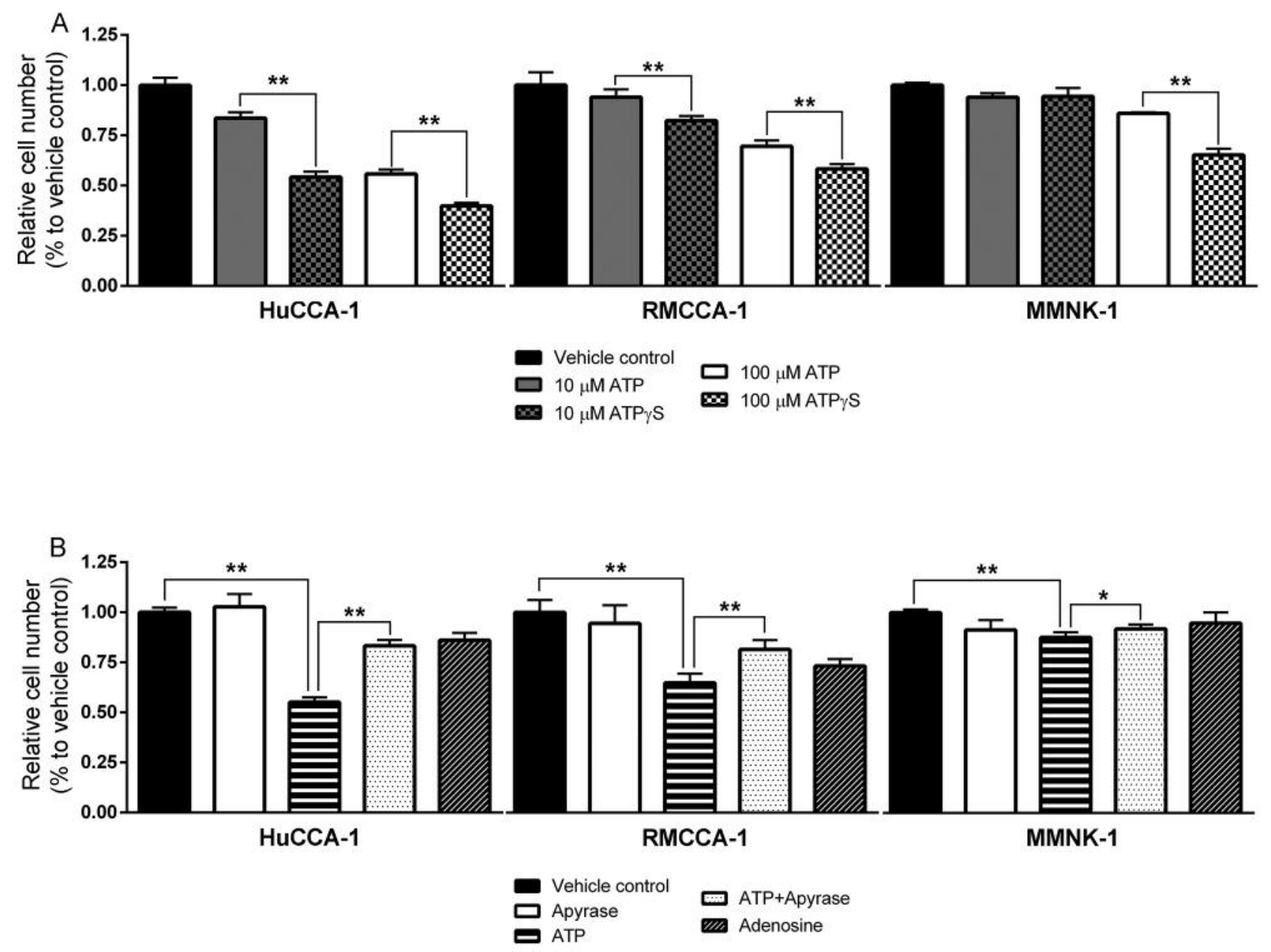

Figure 4. ATP, not its degraded by products, inhibited CCA. MTT assay was performed after 4 days of treatment. (A) A non-hydrolysable ATP analog, ATP $\gamma$ S, showed greater inhibitory effect than ATP. (B) Apyrase, which hydrolyzes ATP ADP and AMP finally, significantly reduced inhibitory effects of ATP on CCA cell proliferation. Experiments were performed in triplicates. ${ }^{*} p<0.05, * * p<0.01$.

RMCCA-1 and MMNK-1, and P2X6 was expressed only on RMCCA-1 cells. No adenosine receptor was expressed in these cell lines (Table II). Primer sequences are listed in Table I.

\section{Discussion}

Herein, ATP and adenosine were reported for the first time to inhibit CCA cell proliferation and motility at doses of 100 $\mu \mathrm{M}$ or higher. Other studies have shown that ATP and adenosine could either inhibite or stimulate cancer cell proliferation and motility. The key factor might be the dose of ATP and adenosine to which cells were exposed. Many studies have shown that a concentration of ATP of $100 \mu \mathrm{M}$ or higher inhibited cancer cell proliferation; while a concentration of ATP lower than $10 \mu \mathrm{M}$ may stimulate cancer cell proliferation. Our group has recently reported the growth inhibition induced byATP at $32 \mu \mathrm{M}(\log [\mathrm{ATP}]=-4.5)$ and higher doses on prostate cancer cell lines (29). In addition, ATP at a very high dose in the range of milli molar was reported to induce cytotoxicity and apoptosis in many cancer types such as hepatoma, adenocarcinoma, and cervical cancer cells $(24,30-33)$. On the other hand, some studies have showed that $10 \mu \mathrm{M}$ ATP and lower doses stimulated growth and motility of ovarian cancer (34), hepatoma (19), breast cancer (23), lung cancer (25), and prostate cancer cells $(20,35)$. To utilize ATP and/or adenosine in vivo, one must consider the final dose of the compounds at the tumor sites. In this study, CCA and immortalized cholangiocyte cell proliferation was not stimulated by either ATP or adenosine alone at low doses (3.16 $\mu \mathrm{M}$ and $10 \mu \mathrm{M}$ ) but RMCCA-1 was stimulated by a combination of ATP and adenosine at $10 \mu \mathrm{M}$ and lower 


\section{A HuCCA-1}

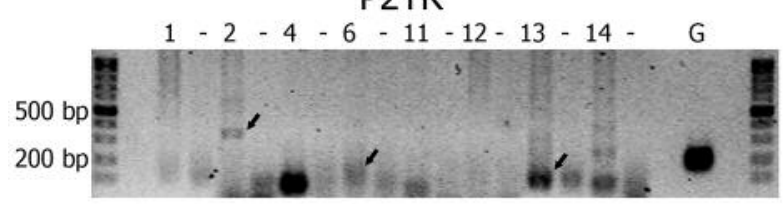

P2XR

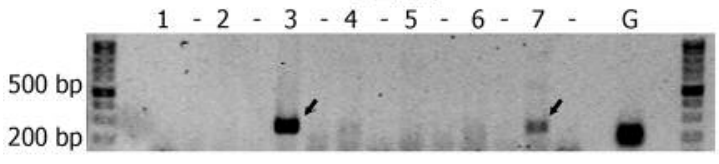

ADORA

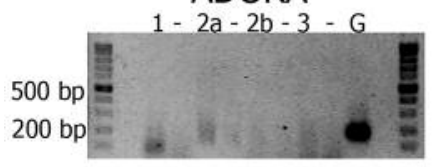

\section{RMCCA-1}

P2YR

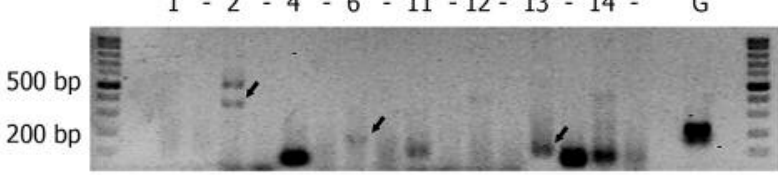

P2XR

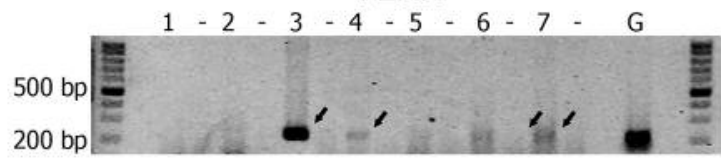

ADORA

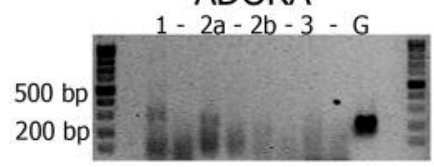

MMNK-1

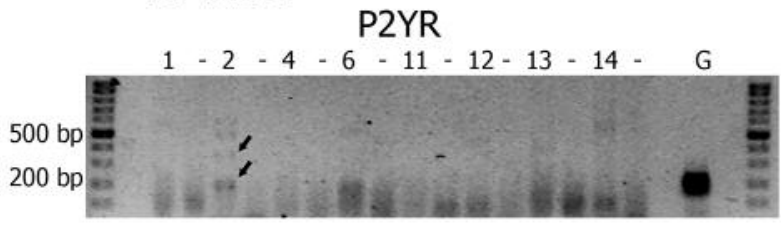

P2XR

$1-2-3-4-5-6-7-G$

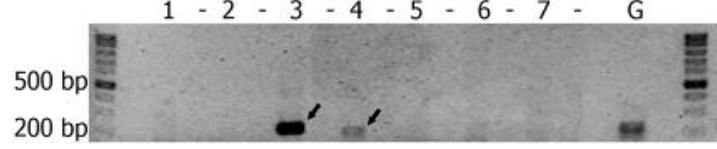

\section{ADORA}

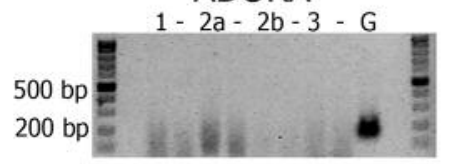

\section{B}

\section{Positive control (HuCCA-1 genomic DNA template)}
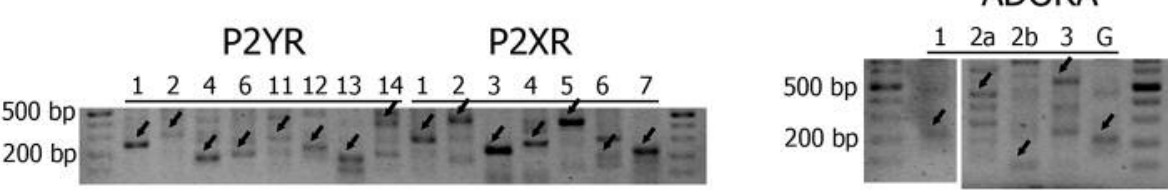

Figure 5. Reverse transcriptase PCR showing transcriptional profile of $P 2 Y$ receptors $(P 2 Y R), P 2 X$ receptors $(P 2 X R)$, and adenosine receptors (ADORA) in CCA cell lines and immortalized cholangiocytes. Positive control used HuCCA-1 genomic DNA as a template. Arrows represent a positive expression of the specified gene. Experiments were performed in triplicates. Picture represents the three replicates.

doses. Therefore, the effects of ATP and adenosine do not only depend on dose but also depend, at least in part, on cell types and the purinergic receptors expressed on the cells.
Furthermore, immortalized cholangiocytes showed resistance to ATP and adenosine treatments. These data can be used in order to find the proper conditions to apply 
Table II. Transcriptional profile of purinergic receptors on CCA cells. Transcriptional profile obtained from reverse transcription PCR + indicates the presence of the specified gene expression.

\begin{tabular}{lccccccr}
\hline Cell line & \multicolumn{7}{c}{ P2RY Subtypes } \\
\cline { 2 - 7 } & 1 & 2 & 4 & 6 & 11 & 12 & 1 \\
\hline HuCCA-1 & - & + & - & + & - & - & + \\
RMCCA-1 & - & + & - & + & - & - & + \\
MMNK-1 & - & + & - & - & - & + & - \\
\hline Cell line & \multicolumn{7}{c}{ ADORA Subtypes } \\
& A1 & A2A & A2B & A3 & & \\
& - & - & - & - & \\
HuCCA-1 & - & - & - & - \\
RMCCA-1 & - & - & - & - \\
MMNK-1 & - & - &
\end{tabular}

adenine compounds as a remedy for CCA. One factor that may be associated with this difference between CCA cells and immortalized cholangiocytes is the variation of purinergic receptor types expressed.

In this study, CCA cell lines and an immortalized cholangiocarcinoma cell line shared a few common P2Y receptors and $\mathrm{P} 2 \mathrm{X}$ receptors, which were $\mathrm{P} 2 \mathrm{Y} 2$ and $\mathrm{P} 2 \mathrm{X} 3$. $\mathrm{P} 2 \mathrm{Y} 2$ receptor was reported to either induce apoptosis (16) or stimulate cell proliferation and cell motility (19-21, 35). However, most studies demonstrated that P2Y2 stimulated cancer cell proliferation and motility rather than suppressed them or induced cell death. Therefore, it might not be the best candidate receptor for the inhibitory effects observed in this study. Although P2X3 receptor was also a common receptor among CCA cell lines and MMNK-1, it was recently reported to induce cell proliferation in hepatocellular carcinoma cell lines and to be associated with poor recurrence-free survival in patients (36). On the other hand, P2Y6, P2Y13, and P2X7 are the receptors that are expressed in CCA cells, but not in immortalized cholangiocarcinoma cells (MMNK-1). Herein, it was demonstrated that MMNK-1 cells showed some resistance to cell proliferation and cell motility inhibition by ATP and adenosine. Therefore, the receptors expressed in CCA cells but not in MMNK-1 cells might be responsible for the aforementioned inhibition. In addition, adenosine was shown to suppress cell proliferation and motility without its receptors expression in CCA cell lines used in this study. Therefore, receptor-independent inhibitory effects of adenosine on CCA cells were suggested. Some researches have demonstrated a receptor-independent inhibition of adenosine on other cancers. Breast and prostate cancer, for example, were shown to be inhibited by adenosine in a receptor-independent manner (37). Further studies are required in order to examine the mechanism of inhibition caused by adenosine on CCA cells.

\section{Acknowledgements}

The Authors would like to thank Assoc. Prof. Rutaiwan Tohtong, for her kindness in providing RMCCA-1 cell line. This study was supported by RD\&E funding (SCH-NR2015-871) from National Science and Technology Development Agency, Thailand.

\section{References}

1 Brito AF, Abrantes AM, Encarnacao JC, Tralhao JG and Botelho MF: Cholangiocarcinoma: from molecular biology to treatment. Med Oncol 32(11): 245, 2015.

2 Moeini A, Sia D, Bardeesy N, Mazzaferro V and Llovet JM: Molecular Pathogenesis and Targeted Therapies of Intrahepatic Cholangiocarcinoma. Clin Cancer Res 22(2): 291-300, 2015.

3 Banales JM, Cardinale V, Carpino G, Marzioni M, Andersen JB, Invernizzi P, Lind GE, Folseraas T, Forbes SJ, Fouassier L, Geier A, Calvisi DF, Mertens JC, Trauner M, Benedetti A, Maroni L, Vaquero J, Macias RI, Raggi C, Perugorria MJ, Gaudio E, Boberg KM, Marin JJ and Alvaro D: Expert consensus document: Cholangiocarcinoma: current knowledge and future perspectives consensus statement from the European Network for the Study of Cholangiocarcinoma (ENS-CCA). Nat Rev Gastroenterol Hepatol 13(5): 261-280, 2016.

4 Furst T, Keiser J and Utzinger J: Global burden of human foodborne trematodiasis: a systematic review and meta-analysis. The Lancet. Infectious diseases 12(3): 210-221, 2012.

5 Kaewpitoon SJ, Rujirakul R, Ueng-Arporn N, Matrakool L, Namwichaisiriku N, Churproong S, Wongkaewpothong $\mathrm{P}$, Nimkuntod P, Sripa B and Kaewpitoon N: Community-based cross-sectional study of carcinogenic human liver fluke in elderly from Surin province, Thailand. Asian Pacific journal of cancer prevention : APJCP 13(9): 4285-4288, 2012.

6 Denlinger CS, Meropol NJ, Li T, Lewis NL, Engstrom PF, Weiner LM, Cheng JD, Alpaugh RK, Cooper H, Wright JJ and Cohen SJ: A phase II trial of the proteasome inhibitor bortezomib in patients with advanced biliary tract cancers. Clinical colorectal cancer 13(2): 81-86, 2014.

7 Doherty B, Nambudiri VE and Palmer WC: Update on the Diagnosis and Treatment of Cholangiocarcinoma. Curr Gastroenterol Rep 19(1): 2, 2017.

8 Di Virgilio F and Adinolfi E: Extracellular purines, purinergic receptors and tumor growth. Oncogene 36(3): 293-303, 2017.

9 Jiang JX, Riquelme MA and Zhou JZ: ATP, a double-edged sword in cancer. Oncoscience 2(8): 673-674, 2015. 
10 Roger S, Jelassi B, Couillin I, Pelegrin P, Besson P and Jiang $\mathrm{LH}$ : Understanding the roles of the $\mathrm{P} 2 \mathrm{X} 7$ receptor in solid tumour progression and therapeutic perspectives. Biochim Biophys Acta 1848(10 Pt B): 2584-2602, 2015.

11 Burnstock G: Short- and long-term (trophic) purinergic signalling. Philos Trans R Soc Lond B Biol Sci 371(1700): pii: 20150422, 2016.

12 Burnstock G: Purinergic Signalling in the Gut. Adv Exp Med Biol 891: 91-112, 2016.

13 Burnstock G: Purinergic signalling in the gastrointestinal tract and related organs in health and disease. Purinergic Signal 10(1): 3-50, 2014.

14 Vaughn BP, Robson SC and Burnstock G: Pathological roles of purinergic signaling in the liver. J Hepatol 57(4): 916-920, 2012.

15 Burnstock G, Vaughn B and Robson SC: Purinergic signalling in the liver in health and disease. Purinergic Signal 10(1): 5170, 2014.

16 Yang G, Zhang S, Zhang Y, Zhou Q, Peng S, Zhang T, Yang C, Zhu Z and Zhang F: The inhibitory effects of extracellular ATP on the growth of nasopharyngeal carcinoma cells via P2Y2 receptor and osteopontin. J Exp Clin Cancer Res 33: 53, 2014.

17 Yang D, He Y, Munoz-Planillo R, Liu Q and Nunez G: Caspase11 Requires the Pannexin-1 Channel and the Purinergic P2X7 Pore to Mediate Pyroptosis and Endotoxic Shock. Immunity 43(5): 923-932, 2015.

18 Adinolfi E, Capece M, Franceschini A, Falzoni S, Giuliani AL, Rotondo A, Sarti AC, Bonora M, Syberg S, Corigliano D, Pinton P, Jorgensen NR, Abelli L, Emionite L, Raffaghello L, Pistoia V and Di Virgilio F: Accelerated tumor progression in mice lacking the ATP receptor P2X7. Cancer Res 75(4): 635-644, 2015.

19 Xie R, Xu J, Wen G, Jin H, Liu X, Yang Y, Ji B, Jiang Y, Song P, Dong $\mathrm{H}$ and Tuo B: The P2Y2 nucleotide receptor mediates the proliferation and migration of human hepatocellular carcinoma cells induced by ATP. J Biol Chem 289(27): 19137-19149, 2014.

20 Li WH, Qiu Y, Zhang HQ, Liu Y, You JF, Tian XX and Fang WG: P2Y2 receptor promotes cell invasion and metastasis in prostate cancer cells. Br J Cancer 109(6): 1666-1675, 2013.

21 Qiu Y, Li WH, Zhang HQ, Liu Y, Tian XX and Fang WG: P2X7 mediates ATP-driven invasiveness in prostate cancer cells. PLoS One 9(12): e114371, 2014.

22 Scodelaro Bilbao P and Boland R: Extracellular ATP regulates FoxO family of transcription factors and cell cycle progression through PI3K/Akt in MCF-7 cells. Biochim Biophys Acta 1830(10): 4456-4469, 2013

23 Jin H, Eun SY, Lee JS, Park SW, Lee JH, Chang KC and Kim HJ: P2Y2 receptor activation by nucleotides released from highly metastatic breast cancer cells increases tumor growth and invasion via crosstalk with endothelial cells. Breast Cancer Res 16(5): R77, 2014.

24 Bian S, Sun X, Bai A, Zhang C, Li L, Enjyoji K, Junger WG, Robson SC and Wu Y: P2X7 integrates PI3K/AKT and AMPKPRAS40-mTOR signaling pathways to mediate tumor cell death. PLoS One 8(4): e60184, 2013.

25 Song S, Jacobson KN, McDermott KM, Reddy SP, Cress AE, Tang H, Dudek SM, Black SM, Garcia JG, Makino A and Yuan JX: ATP promotes cell survival via regulation of cytosolic $\left[\mathrm{Ca}^{2+}\right]$ and Bcl-2/Bax ratio in lung cancer cells. Am J Physiol Cell Physiol 310(2): C99-114, 2016.

26 Rattanasinganchan $\mathrm{P}$, Leelawat $\mathrm{K}$, Treepongkaruna SA, Tocharoentanaphol C, Subwongcharoen S, Suthiphongchai T and
Tohtong R: Establishment and characterization of a cholangiocarcinoma cell line (RMCCA-1) from a Thai patient. World J Gastroenterol 12(40): 6500-6506, 2006.

27 Sirisinha S, Tengchaisri T, Boonpucknavig S, Prempracha N, Ratanarapee S and Pausawasdi A: Establishment and characterization of a cholangiocarcinoma cell line from a Thai patient with intrahepatic bile duct cancer. Asian Pac J Allergy Immunol 9(2): 153-157, 1991.

28 Sripa B, Leungwattanawanit S, Nitta T, Wongkham C, Bhudhisawasdi V, Puapairoj A, Sripa C and Miwa M: Establishment and characterization of an opisthorchiasisassociated cholangiocarcinoma cell line (KKU-100). World J Gastroenterol 11(22): 3392-3397, 2005.

29 Lertsuwan K, Peters W, Johnson L, Lertsuwan J, Marwa I and Sikes RA: Purinergic Receptor Expression and Cellular Responses to Purinergic Agonists in Human Prostate Cancer Cells. Anticancer Res 37(2): 529-537, 2017.

30 Bukhari M, Deng H, Jones N, Towne Z, Woodworth CD and Samways DS: Selective permeabilization of cervical cancer cells to an ionic DNA-binding cytotoxin by activation of P2Y receptors. FEBS Lett 589(13): 1498-1504, 2015.

31 Mello Pde A, Filippi-Chiela EC, Nascimento J, Beckenkamp A, Santana DB, Kipper F, Casali EA, Nejar Bruno A, Paccez JD, Zerbini LF, Wink MR, Lenz G and Buffon A: Adenosine uptake is the major effector of extracellular ATP toxicity in human cervical cancer cells. Mol Biol Cell 25(19): 2905-2918, 2014.

32 Vazquez-Cuevas FG, Martinez-Ramirez AS, Robles-Martinez L, Garay E, Garcia-Carranca A, Perez-Montiel D, Castaneda-Garcia $\mathrm{C}$ and Arellano RO: Paracrine stimulation of P2X7 receptor by ATP activates a proliferative pathway in ovarian carcinoma cells. J Cell Biochem 115(11): 1955-1966, 2014.

33 Wei Q, Zhang Y, Sun L, Jia X, Huai W, Yu C, Wan Z and Han L: High dose of extracellular ATP switched autophagy to apoptosis in anchorage-dependent and anchorage-independent hepatoma cells. Purinergic Signal 9(4): 585-598, 2013.

34 Vinette V, Placet M, Arguin G and Gendron FP: Multidrug resistance-associated protein 2 expression Is up-regulated by Aadenosine 5'-triphosphate in colorectal cancer cells and enhances their survival to chemotherapeutic drugs. PLoS One 10(8): e0136080, 2015.

35 Li WH, Qiu Y, Zhang HQ, Tian XX and Fang WG: P2Y2 Receptor and EGFR cooperate to promote prostate cancer cell invasion via ERK1/2 pathway. PLoS One 10(7): e0133165, 2015.

36 Maynard JP, Lee JS, Sohn BH, Yu X, Lopez-Terrada D, Finegold MJ, Goss JA and Thevananther S: P2X3 purinergic receptor overexpression is associated with poor recurrence-free survival in hepatocellular carcinoma patients. Oncotarget 6(38): 41162-41179, 2015.

37 Virtanen SS, Kukkonen-Macchi A, Vainio M, Elima K, Harkonen PL, Jalkanen S and Yegutkin GG: Adenosine inhibits tumor cell invasion via receptor-independent mechanisms. Mol Cancer Res 12(12): 1863-1874, 2014. 